\title{
Acquisition and Synthesis of Folates by Obligate Intracellular Bacteria of the Genus Chlamydia
}

\author{
Huizhou Fan, Robert C. Brunham, and Grant McClarty \\ Department of Medical Microbiology, University of Manitoba, Winnipeg, Manitoba, Canada R3E OW3
}

\begin{abstract}
We undertook studies focused on folate acquisition by Chlamydia trachomatis L2, Chlamydia psittaci 6BC, and C. psittaci francis. Results from in situ studies, using wild-type host cells, confirmed that $C$. trachomatis $\mathrm{L} 2$ and $C$. psittaci $6 \mathrm{BC}$ are sensitive to sulfonamides whereas $C$. psittaci francis is resistant. In addition $C$. trachomatis $\mathrm{L} 2$ and $C$. psittaci francis were inhibited by methotrexate in situ whereas $C$. psittaci 6BC was not. In contrast to $C$. trachomatis, neither $C$. psittaci strain was affected by trimethoprim. Surprisingly our results indicate that all three strains are capable of efficient growth in folate-depleted host cells. When growing in folate-depleted cells $C$. psittaci francis becomes sensitive to sulfonamide. The ability of all three strains to carry out de novo folate synthesis was demonstrated by following the incorporation of exogenous $\left[{ }^{3} \mathrm{H}\right] \mathrm{pABA}$ into intracellular folates and by detecting dihydropteroate synthase activity in reticulate body crude extract. Dihydrofolate reductase activity was also detected in reticulate body extract. In aggregate the results indicate that $C$. trachomatis L2, $C$. psittaci francis, and $C$. psittaci $6 \mathrm{BC}$ can all synthesize folates de novo, however, strains differ in their ability to transport preformed folates directly from the host cell. (J. Clin. Invest. 1992.90:1803-1811.) Key words: parasite • dihydropteroate synthase $\bullet$ dihydrofolate reductase $\bullet$ sulfonamide $\bullet$ methotrexate
\end{abstract}

\section{Introduction}

Chlamydiae are obligate intracellular bacterial parasites that infect a wide range of host cells and are the causative agents of a variety of human, nonhuman mammal, and avian diseases (15). Chlamydiae display a unique developmental cycle consisting of an infectious extracellular metabolically inert elementary body (EB) ${ }^{1}$ and a noninfectious intracellular metabolically active reticulate body ( $R B$ ). The function of the EB is to survive transit in the extracellular environment until a host is

Address correspondence to Dr. Grant McClarty, Department of Medical Microbiology, University of Manitoba, Room 504, 730 William Avenue, Winnipeg, Manitoba, Canada R3E 0W3.

Received for publication 6 February 1992 and in revised form 21 May 1992.

1. Abbreviations used in this paper: $\mathrm{CHO}$, Chinese hamster ovary; DHFR, dihydrofolate reductase; DHPS, dihydropteroate synthase; EB, elementary body; $\mathbf{H}_{2}$ folate, dihydrofolate; $\mathbf{H}_{4}$ folate, tetrahydrofolate; ID $_{50}$, antimetabolite concentration required to reduce incorporation of radiolabel into DNA by 50\%; pABA, para-aminobenzoic acid; RB, reticulate body.

\section{J. Clin. Invest.}

(c) The American Society for Clinical Investigation, Inc.

0021-9738/92/11/1803/09 \$2.00

Volume 90, November 1992, 1803-1811 encountered. Once inside a host cell EBs differentiate to RBs, which divide by binary fission within the confines of a membrane bound cytoplasmic vacuole. Chlamydiae have an absolute nutritional dependency on the host cell to provide a wide variety of intermediates of metabolism. After multiple rounds of division RBs differentiate back to EBs, which are subsequently released from the host cell to begin a new infection cycle.

The genus chlamydiae is currently divided into three species, Chlamydia trachomatis, Chlamydia psittaci, and Chlamydia pneumoniae (5-7). Classically, the species have been differentiated by inclusion morphology (diffuse vs. compact), presence or absence of glycogen within the inclusion (as determined by iodine staining), and differing sensitivity to sulfa drugs. $C$. trachomatis is sensitive to sulfonamides and they develop diffuse glycogen containing inclusions. In contrast $C$. psittaci, with the exception of strain $6 \mathrm{BC}$, is resistant to sulfa drugs and they give rise to dense inclusions that lack glycogen. C. pneumoniae is also resistant to sulfonamides and they yield dense inclusions that do not contain glycogen.

Sulfonamides are structural analogues and competitive antagonists of para-aminobenzoic acid (pABA), and thus prevent normal bacterial use of pABA for the de novo synthesis of folic acid (8). More specifically, sulfonamides are competitive inhibitors of the bacterial enzyme dihydropteroate synthase (DHPS), which catalyzes the incorporation of pABA into dihydropteroic acid, the immediate precursor of folic acid. As such, microorganisms that are sensitive to sulfonamides must synthesize their own folates and those that can use preformed folates are resistant to sulfa drugs. Mammalian cells are not affected by sulfonamides because they must obtain preformed folates from dietary sources.

The biologically active form of folate is tetrahydrofolate ( $\mathrm{H}_{4}$ folate), which functions as a one-carbon unit carrier in a variety of biosynthetic reactions, including methionine biosynthesis, thymidylate synthesis, and purine biosynthesis $(9,10)$. Thymidylate synthesis is unique among the biosynthetic reactions that employ $\mathrm{H}_{4}$ folate as cofactor in that involves not only the transfer of a one-carbon moiety but also the oxidation of the carrier ( 11$)$. The dihydrofolate $\left(\mathrm{H}_{2}\right.$ folate) formed is converted back to $\mathrm{H}_{4}$ folate by the enzyme dihydrofolate reductase (DHFR). $\mathrm{H}_{4}$ Folate is again converted to a cofactor by the addition of a one-carbon unit as catalyzed by serine hydroxymethyltransferase. Together these reactions form the thymidylate cycle as represented schematically in Fig. 1.

Both $C$. psittaci and $C$. trachomatis have been shown to contain folates different from those present in their host cells $(12,13)$. In addition several studies have shown that chlamydiae cannot use medium-supplied thymidine (14-17), however, they can incorporate exogenously supplied uridine into parasite DNA (15-17). Taken together these results imply that chlamydiae must contain a thymidylate synthase. Recently we have shown that $C$. trachomatis does encode a thymidylate 


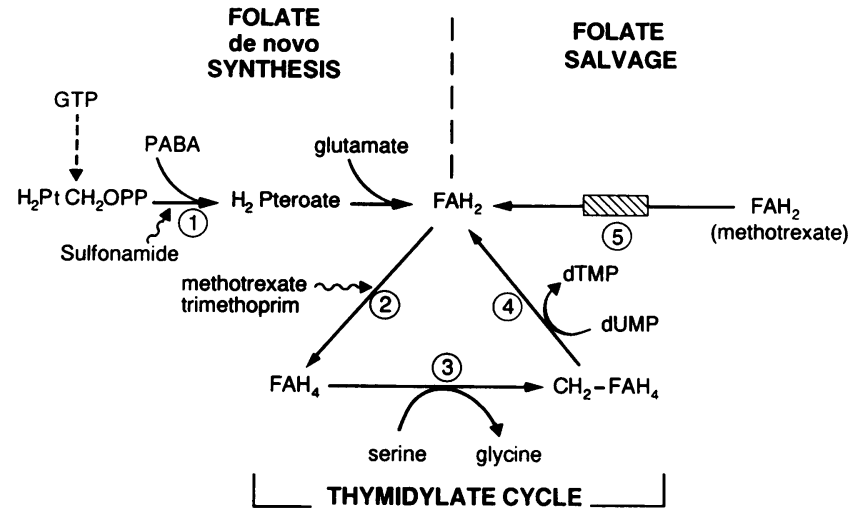

Figure 1. Schematic diagram of the thymidylate cycle and its relation to folate de novo synthesis and salvage. Not all possible routes of metabolism are included, just major routes relevant to this study. Squiggly arrows represent steps inhibited by sulfisoxazole, trimethoprim, and methotrexate. Important enzymes are numbered as follows: 1 , dihydropteroate synthase; 2 , dihydrofolate reductase; 3 , serine hydroxymethyltransferase; 4 , thymidylate synthase; and 5 , a membrane transport system for folates. $\mathrm{FAH}_{2}$, dihydrofolate; $F A H_{4}$, tetrahydrofolate; and $\mathrm{CH}_{2}-\mathrm{FAH}_{4}, 5,10$-methylene tetrahydrofolate.

synthase for synthesis of dTMP from dUMP (17), thus confirming that a folate-requiring reaction exists in chlamydiae. The sulfonamide inhibition studies mentioned above suggest that $C$. trachomatis is capable of de novo folate synthesis whereas $C$. psittaci is not $(12,18-20)$. Since $C$. psittaci also requires folates for thymidine synthesis it has been suggested that they likely have the capacity to transport folates directly from the host cell cytoplasm $(5,12,19)$. Since folates are essential for chlamydial growth and important in taxonomic classification we wanted to clarify the numerous inconsistencies in the existing literature concerning folate metabolism in chlamydiae (for review see reference 5). Our results indicate that both $C$. trachomatis and $C$. psittaci can synthesize folates de novo, however, there appears to be a considerable difference in their ability to obtain preformed folates from the host.

\section{Methods}

Materials. $\left[6-{ }^{3} \mathrm{H}\right]$ Uridine $(20 \mathrm{Ci} / \mathrm{mmol}),\left[3,5-{ }^{3} \mathrm{H}\right] \mathrm{pABA}(50 \mathrm{Ci} /$ $\mathrm{mmol}),\left[3^{\prime}, 5^{\prime} 7,9-{ }^{3} \mathrm{H}\right]$ dihydrofolic acid $\left(\mathrm{H}_{2}\right.$ folate, $\left.38 \mathrm{Ci} / \mathrm{mmol}\right)$ and $\left[3^{\prime}, 5^{\prime} 7,9-{ }^{3} \mathrm{H}\right]$ folic acid $(40 \mathrm{Ci} / \mathrm{mmol})$ were purchased from Moravek Biochemicals (Brea, CA). Unlabeled pABA, para-aminobenzoyl-glutamic acid (pABA-glutamate), folic acid, $\mathrm{H}_{2}$ folate, tetrahydrofolic acid ( $\mathrm{H}_{4}$ folate), 5-formyl-tetrahydrofolic acid (5-CHO- $\mathrm{H}_{4}$ folate), sulfisoxazole, methotrexate, and trimethoprim were purchased from Sigma Chemical Co. (St. Louis, MO). 5,10-Methylenetetrahydrofolic acid $\left(5,10-\mathrm{CH}_{2}-\mathrm{H}_{4}\right.$ folate $)$ was synthesized from $\mathrm{H}_{4}$ folate in the presence of formaldehyde as previously described (17). 10-Formyl-tetrahydrofolic acid (10-CHO- $\mathrm{H}_{4}$ folate) was synthesized from $5-\mathrm{CHO}-\mathrm{H}_{4}$ folate by published procedures (21) . 6-Hydroxymethyl-7,8-dihydropterin pyrophosphate $\left(\mathrm{H}_{2} \mathrm{PtCH}_{2} \mathrm{OPP}\right)$ was kindly provided by $\mathrm{C}$. Allegra, Medicine Branch, National Cancer Institute, Bethesda, MD. All other chemicals were of the highest obtainable purity.

Cell lines and culture conditions. The wild-type Chinese hamster ovary $(\mathrm{CHO}) \mathrm{K} 1$ cell line was purchased from American Type Culture Collection (ATCC; Rockville, MD). The mutant CHO K1 subline deficient in DHFR activity was kindly provided by R. Johnson (22). The wild-type mouse L cells were kindly provided by $\mathrm{K}$. Coombs, Department of Medical Microbiology, University of Manitoba (Winnipeg, Manitoba, Canada).
The mouse $L$ cells were routinely cultured in suspension with minimum essential medium supplemented with $10 \%$ fetal bovine serum and $0.2 \mathrm{mM}$ glutamine. The $\mathrm{CHO} \mathrm{K} 1$ cells were maintained as monolayers at $37^{\circ} \mathrm{C}$ on the surface of plastic tissue culture flasks (Corning Glass Works, Corning Medical and Scientific, Corning, NY). Since the $\mathrm{CHO} \mathrm{K} 1$ cell line is auxotrophic for proline, it was maintained in minimum essential medium supplemented with $10 \%$ fetal bovine serum, $0.2 \mathrm{mM}$ glutamine, and $0.3 \mathrm{mM}$ proline. $\mathrm{CHO}^{\mathrm{DHFR}}{ }^{-}$cells were maintained as monolayer cultures in the same medium supplemented with $10 \%$ fetal bovine serum, $0.3 \mathrm{mM}$ proline, $0.3 \mathrm{mM}$ glycine, $30 \mu \mathrm{M}$ hypoxanthine, and $30 \mu \mathrm{M}$ thymidine. All cell lines were routinely checked for mycoplasma contamination.

Chlamydiae strains and propagation. C. trachomatis strain L2/ 434/ Bu was originally obtained from C. C. Kuo, University of Washington (Seattle, WA) and has been maintained in our laboratory since that time. C. psittaci psittacosis strain 6BC (catalog No. ATCC VR125 ) and meningopneumonitis strain francis (catalog No. ATCC VR122; also called $C$. psittaci $\mathrm{Cal}-10$ ) were purchased from American Type Culture Collection. The authenticity of these strains was periodically confirmed by serologic typing with monoclonal antibodies kindly performed by A. Andersen, United States Department of Agriculture, National Animal Disease Center (Ames, IA). All chlamydial EB stocks were grown in monolayers of mouse L cells and purified by Renografin density gradient centrifugation (17). EB infectivity was titered as previously described (17). Confluent monolayers $\left(3-4 \times 10^{6}\right.$ cells per $5-\mathrm{cm}$ plate) of wild-type CHO K1 and DHFR-deficient $\mathrm{CHO}$ cells were infected at a multiplicity of infection of three to five inclusion-forming units per cell, which resulted in $90-100 \%$ infection with little host cell toxicity. C. trachomatis $\mathrm{L} 2$ and $C$. psittaci $6 \mathrm{BC}$ and francis were grown in the presence of cycloheximide, $1 \mu \mathrm{g} / \mathrm{ml}$ of culture medium, as previously described $(16,17)$. Mock-infected host cell cultures were treated in the same fashion as infected cultures except that chlamydiae were not added.

Suspension cultures of mouse $\mathrm{L}$ cells were used as host for preparing large batches of RBs, which were highly purified through Renografin density gradients as described previously (17). Purified RBs were lysed and extract for enzyme assays was prepared as described by Fan et al. (17).

Measurement of chlamydial DNA synthesis activity in situ. Chlamydial DNA synthesis activity was measured in situ by monitoring the incorporation of $\left[6-{ }^{3} \mathrm{H}\right]$ uridine into DNA in the presence of cycloheximide as previously described $(16,17)$. This DNA synthesis assay specifically measures chlamydial DNA synthesis activity and provides an accurate and reliable estimation of chlamydial growth (16). Unless otherwise indicated, all results are expressed in $10^{3} \mathrm{dpm}$ incorporated per $10^{6}$ cells. For antimetabolite- or antagonist-treated cultures, incorporation values are expressed as percentages of the amount of radiolabel incorporated into DNA by untreated controls. The $\mathrm{ID}_{s 0}$ value is the antimetabolite concentration required to reduce incorporation of radiolabel into DNA by $50 \%$.

Incorporation of $\left[{ }^{3} \mathrm{H}\right] p A B A$ into chlamydial folates in situ. Results from preliminary experiments indicated that $\left[{ }^{3} \mathrm{H}\right] \mathrm{pABA}$ incorporation by chlamydiae was greater if the host $\mathrm{CHO} \mathrm{K} 1$ cells were depleted of intracellular folates. As a result, all $\left[{ }^{3} \mathrm{H}\right]$ pABA-labeling experiments were done with $\mathrm{CHO} \mathrm{K} 1$ cells that had been starved for folates before radiolabeling. To deplete $\mathrm{CHO} \mathrm{K} 1$ cells of intracellular folates, cultures were grown for 10 passages in folate- and pABA-free Dulbecco modified Eagle medium (DME H-21), obtained from the Tissue Culture Facility, University of California (San Francisco, CA), supplemented with $10 \%$ extensively dialyzed fetal bovine serum, $0.3 \mathrm{mM}$ proline, 0.3 $\mathrm{mM}$ glycine, $30 \mu \mathrm{M}$ hypoxanthine, and $30 \mu \mathrm{M}$ thymidine. Since chlamydiae are auxotrophic for purine ribonucleotides, glycine, and proline it was necessary to keep these supplements in the culture medium after infection with chlamydiae and during the subsequent radiolabeling period.

$\left[{ }^{3} \mathrm{H}\right]$ pABA-labeling experiments were performed with parallel flasks $\left(150 \mathrm{~cm}^{2}\right)$ of mock-infected and chlamydiae-infected folate-depleted $\mathrm{CHO} \mathrm{K} 1$ cells $\left(30-40 \times 10^{6}\right.$ cells per $150-\mathrm{cm}^{2}$ flask $)$. Immedi- 
ately after infection with chlamydiae the cell monolayer was rinsed with Hanks' buffered saline, then $15 \mathrm{ml}$ of DME H-21 medium supplemented with $10 \%$ dialyzed fetal bovine serum, $0.3 \mathrm{mM}$ proline, 0.3 $\mathrm{mM}$ glycine, $30 \mu \mathrm{M}$ hypoxanthine, $1 \mu \mathrm{g} / \mathrm{ml}$ cycloheximide, and $30 \mu \mathrm{Ci}$ $\left[{ }^{3} \mathrm{H}\right]$ pABA was added to each flask. The cultures, both mock- and chlamydiae-infected, were incubated at $37^{\circ} \mathrm{C}$ for $24 \mathrm{~h}$ and then the cells were harvested and intracellular folates were extracted as previously described (23). Briefly, the monolayers were washed five times with ice-cold PBS then the cells were harvested in $1 \mathrm{ml}$ of PBS by scraping the surface of the flask with a rubber policeman. The cells were heated at $100^{\circ} \mathrm{C}$ for $1 \mathrm{~min}$ in $3 \%$ sodium ascorbate, $\mathrm{pH} 6.0$, and 3\% 2-mercaptoethanol and then the cell debris were removed by centrifugation. The cell supernatant was treated with $0.5 \mathrm{ml}$ of partially purified hog kidney polyglutamate hydrolase, prepared according to the method of McMartin et al. (24), at $37^{\circ} \mathrm{C}$ for $30 \mathrm{~min}$ to convert all folates to monoglutamates. After an additional boiling with ascorbate and 2mercaptoethanol, the folates were extracted into methanol using a C-18 cartridge (Sep-Pak; Waters Chromatography Division, Milford, MA) and concentrated under a steady stream of nitrogen. The dried sample was dissolved in $100 \mu \mathrm{l}$ of $5 \mathrm{mM}$ PIC A (Waters Chromatography Division ) and the individual folates were resolved by HPLC using a C-8 $\mu$ Bondapak column ( $12.5 \mathrm{~cm}$; Whatman International, Clifton, $\mathrm{NJ})$ under isocratic conditions; the mobile phase consisted of $22.5 \%$ methanol and $77.5 \% 5 \mathrm{mM}$ PIC A, pH 5.5. Isotope incorporation into individual folates was determined by in-line radioactive flow detection ( 171 detector; Beckman Instruments, Fullerton, CA). The identity of the radioactive peaks was confirmed by simultaneously monitoring the $\mathrm{A}_{290}$ ( $1066 \mathrm{UV}$ detector; Beckman Instruments) of known unlabeled folate standards that were coinjected with each sample. Data were collected and processed with an IBM PC 50 using Beckman System Gold software.

Assay of DHPS activity in vitro. DHPS was assayed by previously described procedures (25) with the following modifications. The DHPS assay mix contained, in a final volume of $100 \mu \mathrm{l}, 100 \mathrm{mM}$ Tris- $\mathrm{HCl}$ ( $\mathrm{pH} \mathrm{8.5)}$ ), $5 \mathrm{mM} \mathrm{NaF}, 10 \mathrm{mM} \mathrm{MgCl}_{2}, 10 \mu \mathrm{M} \mathrm{H}_{2} \mathrm{PtCH}_{2} \mathrm{OPP}$, $1 \mu \mathrm{M}\left[{ }^{3} \mathrm{H}\right] \mathrm{pABA}(10 \mu \mathrm{Ci} / \mathrm{ml})$, and $5 \mathrm{mM}$ dithiothreitol. The reaction was initiated by the addition of $150 \mu \mathrm{g} \mathrm{RB}$ extract protein as a source of enzyme and then was allowed to proceed at $37^{\circ} \mathrm{C}$ for $60 \mathrm{~min}$. The reaction was terminated by the addition of $100 \mu \mathrm{l}$ of $3 \%$ ascorbate/3\% 2-mercaptoethanol followed by boiling for $1 \mathrm{~min}$. The resulting precipitate was removed by centrifugation $(14,000 \mathrm{~g}$ for $10 \mathrm{~min}$ ) and then 50 $\mu \mathrm{l}$ of the supernatant was spotted onto $3 \times 30-\mathrm{cm}$ strips of $3 \mathrm{MM}$ chromatography paper (Whatman International). The strips were developed in a descending chromatography tank using a mobile phase buffer of $0.1 \mathrm{M} \mathrm{KH}_{2} \mathrm{PO}_{4}$, $\mathrm{pH} 7.0$. Once the buffer front had traveled $20 \mathrm{~cm}$, the paper strip was removed from the chromatography tank, the origin containing the labeled product was cut from the strip, dried, and placed in a scintillation vial containing $10 \mathrm{ml}$ cocktail (Universol; ICN Biomedicals, Inc., Costa Mesa, CA). The vial was left at room temperature for $16 \mathrm{~h}$ and then it was counted in a liquid scintillation counter (LS 5000; Beckman Instruments).

Assay of DHFR activity in vitro. DHFR assays were carried out essentially as described by Baccanari et al. (26). The complete reaction mixture contained, in a total volume of $100 \mu 1,50 \mathrm{mM}$ Tris- $\mathrm{HCl}(\mathrm{pH}$ 7.5), $1 \mathrm{mM}$ dithiothreitol, $200 \mu \mathrm{M} \mathrm{NADPH}, 100 \mu \mathrm{M}\left[{ }^{3} \mathrm{H}\right] \mathrm{H}_{2}$ folate $(10 \mu \mathrm{Ci} / \mathrm{ml})$ or $\left[{ }^{3} \mathrm{H}\right]$ folate $(10 \mu \mathrm{Ci} / \mathrm{ml})$, and $150 \mu \mathrm{g}$ of $\mathrm{RB}$ extract protein as a source of enzyme. The reaction was allowed to proceed at $30^{\circ} \mathrm{C}$ for $10 \mathrm{~min}$ and then the reaction was terminated by the addition of $100 \mu \mathrm{l}$ of $3 \%$ ascorbate/3\% 2-mercaptoethanol followed by boiling for $1 \mathrm{~min}$. Precipitated protein was removed by centrifugation and the radiolabeled folic acid, $\mathrm{H}_{2}$ folate, and $\mathrm{H}_{4}$ folate present in the supernatant were resolved by HPLC using a C-18 $\mu$ Bondapak column ( 12.5 $\mathrm{cm}$; Whatman International) under isocratic conditions; the mobile phase consisted of $5 \mathrm{mM}$ PIC A, $10 \mathrm{mM}\left(\mathrm{NH}_{4}\right) \mathrm{H}_{2} \mathrm{PO}_{4}$ ( $\mathrm{pH} 7.3$ ), $20 \%$ methanol, and $5 \%$ acetonitrile. The identity of the radioactive folate peaks was confirmed by simultaneously monitoring the $A_{290}$ of known folate, $\mathrm{H}_{2}$ folate, and $\mathrm{H}_{4}$ folate standards coinjected with each sample. Data were collected and analyzed as described above.

\section{Results}

Effect of various inhibitors of folate metabolism on chlamydiae growth. Initially we wanted to determine the effects of various inhibitors of folate metabolism on the growth of $C$. trachomatis and $C$. psittaci. Chlamydial growth was monitored by measuring the incorporation of $\left[{ }^{3} \mathrm{H}\right]$ uridine into DNA in the presence of the eucaryotic protein synthesis inhibitor cycloheximide (16). For historical reasons we used the commonly studied $C$. trachomatis strain L2 as well as $C$. psittaci psittacosis strain 6BC and $C$. psittaci meningopneumonitis strain francis (frequently referred to as $C$. psittaci Cal-10). Three drugs that target folate metabolism were tested. Sulfisoxazole, a competitive inhibitor of dihydropteroate synthase, inhibits de novo folate synthesis (8); trimethoprim, an inhibitor of bacterial DHFR that enters cells by simple diffusion (27); and methotrexate, an aminopterin analogue that inhibits both mammalian and bacterial DHFR $(28,29)$. In vivo methotrexate is only effective against cells that have a transport system(s) for folates $(28,30)$.

Results of experiments determining the effect of various concentrations of these three inhibitors on chlamydial growth in wild-type $\mathrm{CHO} \mathrm{K} 1$ cells are shown in Fig. 2. In keeping with earlier findings $(12,18-20)$, sulfisoxazole was an effective inhibitor of both $C$. trachomatis strain L2 and $C$. psittaci strain 6BC growth. The concentration of sulfisoxazole required to inhibit DNA synthesis by $50 \%\left(\mathrm{ID}_{50}\right)$ was $0.4 \mu \mathrm{M}$ for $C$. trachomatis $\mathrm{L} 2$ and $0.5 \mu \mathrm{M}$ for $C$. psittaci $6 \mathrm{BC}$. Also in agreement with previous reports $(5,31)$ we found that sulfisoxazole had no effect on $C$. psittaci francis DNA synthesis. Trimethoprim was effective against $C$. trachomatis $\mathrm{L} 2$, having an $\mathrm{ID}_{50}$ of 0.5 $\mu \mathrm{M}$. In contrast neither of the $C$. psittaci strains were sensitive to trimethoprim. Both $C$. trachomatis $\mathrm{L} 2$ and $C$. psittaci francis were inhibited by methotrexate, having $\mathrm{ID}_{50}$ values of 3.2 and $0.3 \mu \mathrm{M}$, respectively. Growth of $C$. psittaci $6 \mathrm{BC}$ was unaffected by methotrexate even at concentrations as high as 100 $\mu \mathrm{M}$ (data not shown). Since the chlamydial ID $_{50}$ values for methotrexate are much higher than the $\mathrm{ID}_{50}$ values for mammalian cell lines $(28,29)$ it is difficult to determine whether methotrexate inhibits chlamydiae directly or indirectly via an effect on the host cell line. This is particularly relevant when one considers that methotrexate inhibits de novo purine biosynthesis in mammalian cells $(28,29)$ and chlamydiae are auxotrophic for purine ribonucleotides $(4,5)$. To determine whether methotrexate directly affects chlamydiae replication, we used a DHFR-deficient $\mathrm{CHO}$ cell line as a host to support parasite growth. As a result of the DHFR deficiency this cell line is unable to regenerate $\mathrm{H}_{4}$ folate from $\mathrm{H}_{2}$ folate and is unaffected by methotrexate $(17,22)$. Methotrexate was an effective inhibitor of chlamydial growth in this cell line (Fig. 3). The concentration of methotrexate required to inhibit $C$. trachomatis $\mathrm{L} 2$ and $C$. psittaci francis DNA synthesis activity by $50 \%$ in this cell line was 4.8 and $2.0 \mu \mathrm{M}$, respectively. As was the case with wild-type cells as host, $C$. psittaci $6 \mathrm{BC}$ growth was unaffected by methotrexate in the DHFR-deficient cell line (data not shown).

Growth of chlamydiae in host cells depleted of folates and $p A B A$. To evaluate the requirement of chlamydiae for exogenous folates we tested the ability of the parasite to grow in wild-type $\mathrm{CHO} \mathrm{K} 1$ cells with depleted intracellular folate pools. To achieve maximal folate depletion we grew the $\mathrm{CHO}$ $\mathrm{K} 1$ cells for 10 passages in folate- and $\mathrm{pABA}$-free medium sup- 


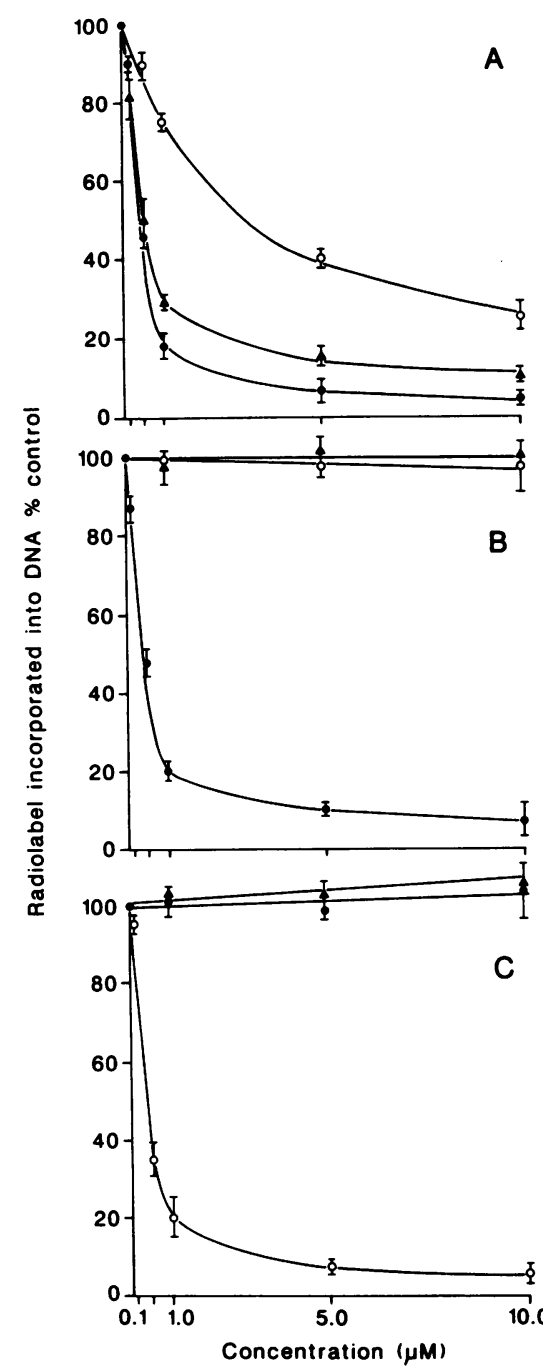

Figure 2. Effect of sulfisoxazole, trimethoprim, and methotrexate on $\left[6-{ }^{3} \mathrm{H}\right]$ uridine incorporation into DNA in $(A)$ $C$. trachomatis $\mathrm{L} 2-$, (B) C. psittaci 6BC-, and $(C) C$. psittaci francis-infected wildtype $\mathrm{CHO} \mathrm{K} 1$ cells $(4.0$ $\times 10^{6}$ cells per plate cultured in the presence of $1 \mu \mathrm{g}$ cycloheximide/ $\mathrm{ml}$ ). The indicated concentrations of sulfisoxazole $(\bullet)$, trimethoprim (A), or methotrexate $(0)$ were added immediately after infection with chlamydiae i.e., $2 \mathrm{~h}$ postinfection (p.i.). Radiolabeled uridine (final concentration $0.3 \mu \mathrm{M}$ ) was added at $20 \mathrm{~h}$ p.i. Cell culture conditions, chlamydiae infection procedure, and ${ }^{3} \mathrm{H}$-labeling procedure are as described in Methods and reference 17. The amount of radiolabel incorporated into DNA is expressed as a percentage of the uninhibited control. The following are $100 \%$ control values: $C$. trachomatis L2-infected cultures, $158,954 \pm 17,963 \mathrm{dpm} /$ $10^{3}$ cells; $C$. psittaci $6 \mathrm{BC}$-infected cultures, $178,692 \pm 22,753 \mathrm{dpm} /$ $10^{6}$ cells; and C. psittaci francis-infected cultures, 143,650 $\pm 13,098$ $\mathrm{dpm} / 10^{6}$ cells. The data represent the average of two determinations. Bars, SD.

plemented with hypoxanthine, proline, glycine, and thymidine. Results presented in Table I indicate that all three chlamydial strains grew as well in $\mathrm{CHO} \mathrm{K} 1$ cells extensively starved for folates and pABA as they did in host cells that had been previously cultured in complete medium. The observation that C. trachomatis $\mathrm{L} 2$ and $C$. psittaci $6 \mathrm{BC}$ could grow in folate-depleted host cells is in keeping with their sulfa sensitivity and further supports the suggestion that these two strains can synthesize folates de novo. However, given that $C$. psittaci francis was resistant to sulfonamide (a result that suggested that it could obtain preformed folates from the host) we were surprised that it could grow so well in host cells depleted of folates. To help clarify this paradox we checked the sulfonamide sensitivity of $C$. psittaci francis growing in host cells depleted of folates. The results clearly showed that, in contrast to the findings with folate-replete cells, $C$. psittaci francis was highly susceptible to sulfisoxazole inhibition when grown in folatestarved cells (Fig. 4). With $C$. psittaci francis-infected folatestarved cells the $\mathrm{ID}_{50}$ for sulfonamide was $1.0 \mu \mathrm{M}$.
Incorporation of $\left[{ }^{3} \mathrm{H}\right] p A B A$ into chlamydial folates. To directly test if chlamydiae could synthesize folates de novo we determined the ability of all three strains to incorporate radiolabeled pABA into their folate pools. For these studies all chlamydial strains were grown in folate-depleted $\mathrm{CHO} \mathrm{K} 1$ cells in the presence of $\left[{ }^{3} \mathrm{H}\right]$ pABA. Fig. 5 shows typical elution profiles obtained after HPLC separation of radiolabeled folates extracted from C. trachomatis $\mathrm{L2}-, C$. psittaci 6BC-, and $C$. psittaci francis-infected folate-starved CHO K1 cells. As expected, CHO K1 cells were unable to use $\left[{ }^{3} \mathrm{H}\right] \mathrm{pABA}$ for the synthesis of folates (data not shown). All three chlamydial strains incorporated $\left[{ }^{3} \mathrm{H}\right]$ pABA into their folate pools; however, there are obvious differences in the elution profiles obtained for reduced folates when $C$. trachomatis and $C$. psittaci are compared. The major reduced folates produced by $C$. trachomatis $\mathrm{L} 2$ were $\mathrm{H}_{4}$ folate and $10-\mathrm{CHO}-\mathrm{H}_{4}$ folate; variable amounts of $5-\mathrm{CH}_{3}-\mathrm{H}_{4}$ folate or $5,10-\mathrm{CH}_{2}-\mathrm{H}_{4}$ folate (the two peaks coeluted) were also routinely detected. In contrast, the predominant reduced folate produced by $C$. psittaci strain 6BC was $10-\mathrm{CHO}-\mathrm{H}_{4}$ folate; with variable amounts of $\mathrm{H}_{4}$ folate, 5-CHO- $\mathrm{H}_{4}$ folate, and $5-\mathrm{CH}_{3} \mathrm{H}_{4}$ folate also being detected. C. psittaci strain francis produced variable amounts of 10 CHO- $\mathrm{H}_{4}$ folate, $\mathrm{H}_{4}$ folate, and 5- $\mathrm{CH}_{3}$ folate and/or $5,10-\mathrm{CH}_{2-}$ $\mathrm{H}_{4}$ folate. Sulfisoxazole $(10 \mu \mathrm{M})$ was effective in preventing the incorporation of $\left[{ }^{3} \mathrm{H}\right] \mathrm{pABA}$ into folates by all three chlamydial strains.

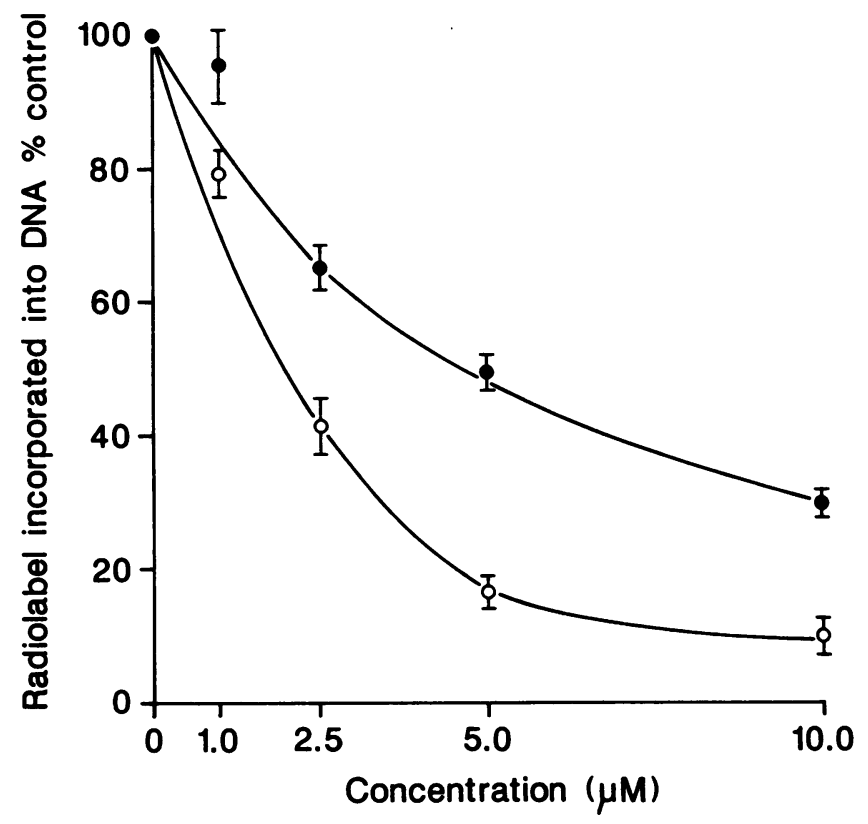

Figure 3. Effect of methotrexate on $\left[6-{ }^{3} \mathrm{H}\right]$ uridine incorporation into DNA in C. trachomatis $\mathrm{L} 2-(\bullet)$ and $C$. psittaci francis $(0)$-infected DHFR-deficient $\mathrm{CHO} \mathrm{K} 1$ cells $\left(4 \times 10^{6}\right.$ cells per plate cultured in complete medium supplemented with proline, glycine, and hypoxanthine in the presence of $1 \mu \mathrm{g}$ cycloheximide $/ \mathrm{ml}$ ). The indicated concentrations of methotrexate were added to the culture medium at $2 \mathrm{~h}$ p.i. Radiolabeled uridine was added at $20 \mathrm{~h}$ p.i. Cell culture conditions, chlamydiae infection procedure, and ${ }^{3} \mathrm{H}$-labeling conditions are as described in Methods and reference 17. The amount of radiolabel incorporated into DNA is expressed as a percentage of the uninhibited control. The following are $100 \%$ control values: $C$. trachomatis $\mathrm{L2}-$ infected cultures, $124,763 \pm 14,980 \mathrm{dpm} / 10^{6}$ cells and $C$. psittaci francis-infected cultures, $142,822 \pm 16,587 \mathrm{dpm} / 10^{6}$ cells. The data represent the average of two determinations. Bars, SD. 
Table I. Effect of Exogenous Folate on the Growth of Chlamydiae in Chinese Hamster Ovary K1 Cells

\begin{tabular}{cllccc}
\hline & & \multicolumn{3}{c}{ DNA synthesis $^{*}$} \\
\cline { 3 - 6 } Cell line & \multicolumn{1}{c}{$\begin{array}{c}\text { Culture } \\
\text { medium }\end{array}$} & $\begin{array}{c}\text { Mock } \\
\text { infected }\end{array}$ & $\begin{array}{c}\text { C. trachomatis } \\
\text { L2 }\end{array}$ & $\begin{array}{c}\text { C. psittaci } \\
\text { 6BC }\end{array}$ & $\begin{array}{c}\text { C. psittaci } \\
\text { francis }\end{array}$ \\
\hline CHO K1 & Folate containing & $0.9 \pm 0.1$ & $162.6 \pm 16.8$ & $197.9 \pm 10.7$ & $189.4 \pm 9.2$ \\
CHO K1 & Folate free & $0.7 \pm 0.2$ & $151.2 \pm 12.1$ & $191.0 \pm 16.1$ & $197.4 \pm 16.8$
\end{tabular}

* Before chlamydial infection, $\mathrm{CHO}$ K1 cells were cultured in complete medium containing $2.2 \mu \mathrm{M}$ folate or were depleted of intracellular folates by passage in folate- and pABA-free medium. For details, see methods and text. ${ }^{\ddagger}$ The effect of exogenous folate on chlamydiae growth was assessed by measuring $\left[6-{ }^{3} \mathrm{H}\right]$ uridine incorporation into DNA at $20 \mathrm{~h}$ p.i. Folate-replete or folate-depleted CHO K1 cells were either mock- or chlamydiae-infected confluent monolayers $\left(3.0 \times 10^{6}\right.$ cells per plate cultured in the presence of $1 \mu \mathrm{g}$ cycloheximide/ml). For details see Methods and reference 17. Each value represents the mean \pm SD from two experiments. Results are expressed in $10^{3} \mathrm{dpm}$ per $10^{6} \mathrm{cells}$.

Detection of in vitro DHPS activity in chlamydial extracts. To conclusively show that chlamydiae contain DHPS, we prepared extracts from highly purified $C$. trachomatis $\mathrm{L} 2$ and $C$. psittaci strains $6 \mathrm{BC}$ and francis $\mathrm{RBs}$ and then assayed for DHPS activity in vitro. DHPS activity was measured by following the synthesis of dihydropteroate from $\left[{ }^{3} \mathrm{H}\right] \mathrm{pABA}$ and 6-hydroxymethyl-7,8-dihydropterin pyrophosphate. We consistently detected DHPS activity using RB extract prepared from any one of the three chlamydial strains as a source of enzyme. $\mathrm{RB}$ extracts prepared from $C$. trachomatis $\mathrm{L} 2, C$. psittaci $6 \mathrm{BC}$,

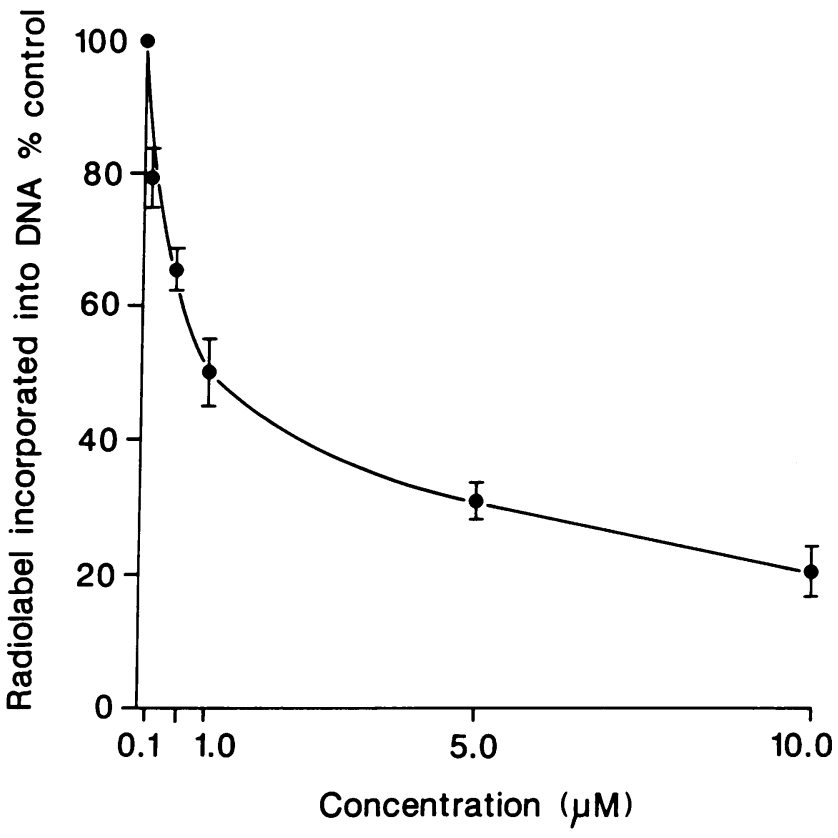

Figure 4. The effect of sulfisoxazole on $\left[6-{ }^{3} \mathrm{H}\right]$ uridine incorporation into DNA in C. psittaci francis-infected folate- and pABA-depleted wild-type $\mathrm{CHO} \mathrm{K} 1$ cells $\left(4 \times 10^{6}\right.$ cells per plate cultured in folateand pABA-free medium supplemented with proline, glycine, and hypoxanthine in the presence of $1 \mu \mathrm{g}$ cycloheximide $/ \mathrm{ml}$ ). The indicated concentrations of sulfisoxazole were added to the culture medium at $2 \mathrm{~h}$ p.i. Radiolabeled uridine was added at $20 \mathrm{~h}$ p.i. Cell culture conditions, chlamydiae infection procedure, and ${ }^{3} \mathrm{H}$-labeling procedure were as described in Methods and reference 17. The amount of radiolabel incorporated into DNA is expressed as a percentage of the uninhibited control. The following is the $100 \%$ control value: $C$. psittaci francis-infected cultures, $169,094 \pm 15,386 \mathrm{dpm} / 10^{6}$ cells. The data represent the average of two determinations. Bars, SD. and C. psittaci francis catalyzed the synthesis of $3.1 \pm 0.5$, $6.5 \pm 1.6$, and $2.8 \pm 0.3 \mathrm{pmol}$ dihydropteroate product $/ \mathrm{min}$ per $\mathrm{mg}$ protein, respectively. The DHPS activity detected from all strains was inhibited $\geq 90 \%$ by $10 \mu \mathrm{M}$ sulfisoxazole.
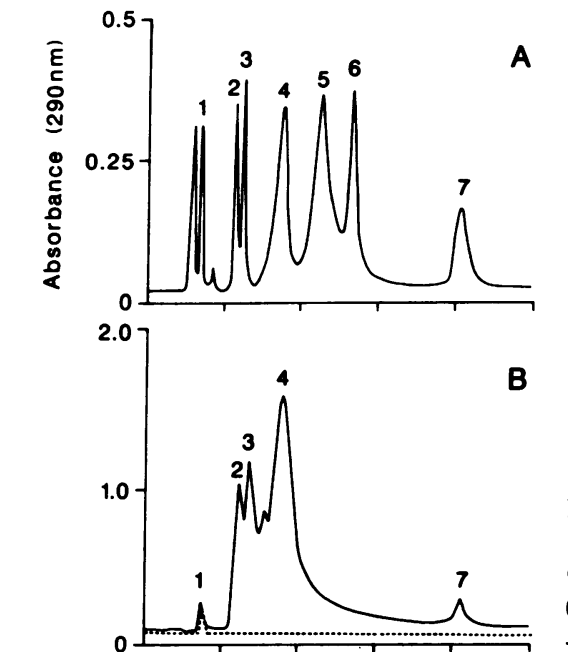

Figure 5. (A) Ultraviolet $\left(\mathrm{A}_{290}\right)$ absorption profile of folate standards separated by HPLC. Peaks identified were: 1 , pABA; 2 , pABA-glutamate; 3, 10 CHO- $\mathrm{H}_{4}$ folate; $4, \mathrm{H}_{4}$ folate; $5,5-\mathrm{CHO}-\mathrm{H}_{4}$ folate; 6, $\mathrm{H}_{2}$ folate; 7, 5- $\mathrm{CH}_{3}-$ $\mathrm{H}_{4}$ folate and/or 5,10$\mathrm{CH}_{2}-\mathrm{H}_{4}$ folate. (B) Radioactive profile after incorporation of $\left[{ }^{3} \mathrm{H}\right]$ pABA into folates by C. trachomatis $\mathrm{L} 2-,(C)$ C. psittaci 6BC-, and (D) C. psittaci francis -infected folate- and pABA-depleted wildtype $\mathrm{CHO} \mathrm{K} 1$ cells
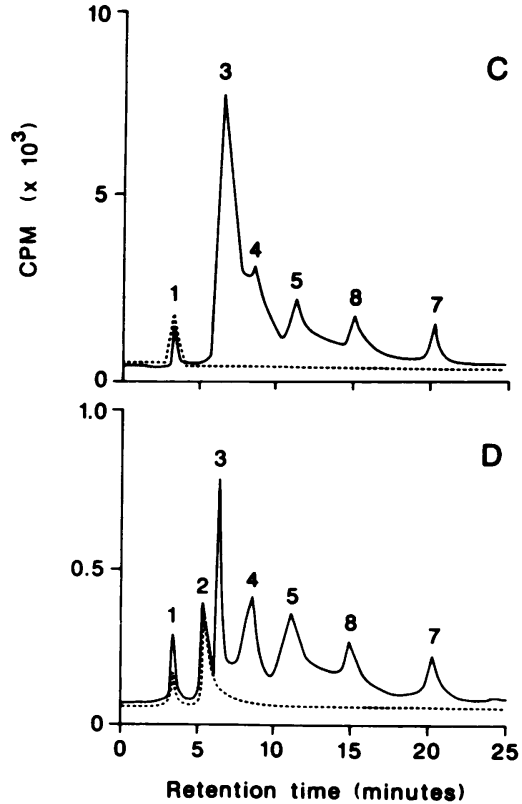

$\left(30.0 \times 10^{6}\right.$ cells per flask cultured in folateand pABA-free medium supplemented with proline, glycine, and hypoxanthine in the presence of $1 \mu \mathrm{g}$ cycloheximide/ $\mathrm{ml})$. Cell culture conditions, chlamydiae infection procedure, $\left[{ }^{3} \mathrm{H}\right]-$ pABA-labeling conditions, folate extraction procedure, and HPLC conditions are as described in Methods and text. Solid line represents radioactivity detected from folates isolated from chlamydiaeinfected control cultures and the broken line represents radioactivity detected from folates extracted from chlamydiae-infected cultures treated with $10 \mu \mathrm{M}$ sulfisoxazole. Radioactive peak 8 in the $C$. psittaci chromatograms was not identified. 
Reversal of sulfisoxazole inhibition by $p A B A$ and folates. It has been shown with numerous experimental systems that the inhibitory action of sulfa drugs can be antagonized by pABA (8). Results presented in Fig. 6 indicate that, with folate- and pABA-depleted $\mathrm{CHO} \mathrm{K} 1$ cells as host, the growth inhibition caused by $1 \mu \mathrm{M}$ sulfisoxazole (Fig. $6 A-C$, hatched bars) on all three strains of chlamydiae can be completely reversed by 0.1 $\mu \mathrm{M}$ pABA (Fig. $6 A-C$, cross-hatched bars). With $C$. psittaci francis, $10 \mu \mathrm{M}$ folic acid completely reversed the inhibition caused by $1 \mu \mathrm{M}$ sulfisoxazole (Fig. $6 C$, square-checked bar). Even $1 \mu \mathrm{M}$ folic acid was sufficient to reverse $1 \mu \mathrm{M}$ sulfisoxazole-induced inhibition (data not shown). In contrast, folic acid was much less effective at reversing the effects of sulfa on $C$. trachomatis $\mathrm{L} 2$ and $C$. psittaci $6 \mathrm{BC}$, showing essentially no antagonism at $10 \mu \mathrm{M}$ (Fig. $6 A$ and $B$, square-checked bars) and only partial reversion at $100 \mu \mathrm{M}$ (data not shown). We found that the inhibitory effects of $1 \mu \mathrm{M}$ sulfisoxazole on $C$. trachomatis $\mathrm{L} 2$ and $C$. psittaci francis could be partially and completely reversed, respectively, by $1 \mu \mathrm{M} 5-\mathrm{CHO}-\mathrm{H}_{4}$ folate (Fig. $6 A$ and $C$, dotted bar). At a concentration of $10 \mu \mathrm{M}$,

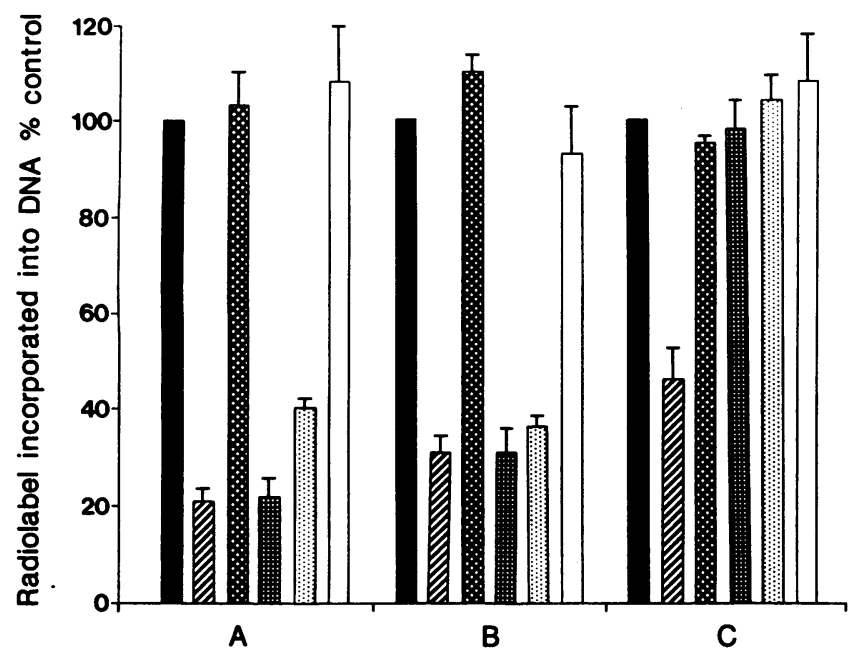

Figure 6. $(A)$ Effect of exogenous pABA and folates on the sulfisoxazole induced inhibition of $C$. trachomatis $\mathrm{L} 2,(B) C$. psittaci $6 \mathrm{BC}$, and $(C) C$. psittaci francis DNA synthesis. Chlamydiae-infected folate and pABA-depleted wild-type $\mathrm{CHO} \mathrm{K1}$ cells $\left(4.0 \times 10^{6}\right.$ cells per plate cultured in folate- and pABA-free medium supplemented with proline, glycine, and hypoxanthine in the presence of $1 \mu \mathrm{g}$ cycloheximide $/ \mathrm{ml}$ ) were incubated in the absence or presence of sulfisoxazole, pABA, and/or folates. The indicated components were added at 2 $\mathrm{h}$ p.i., and then at $20 \mathrm{~h}$ p.i. the cultures were pulsed with radiolabeled uridine. Cell culture conditions, chlamydiae infection procedure, and ${ }^{3} \mathrm{H}$-labeling conditions are as described in Methods and reference 17. The amount of radiolabel incorporated into DNA is expressed as a percentage of the uninhibited controls. The $100 \%$ control values are as follows: $C$. trachomatis $\mathrm{L} 2$-infected cultures, $138,034 \pm 15,984$ $\mathrm{dpm} / 10^{6}$ cells; $C$. psittaci $6 \mathrm{BC}$-infected cultures, $165,428 \pm 19,683$ $\mathrm{dpm} / 10^{6}$ cells, and $C$. psittaci francis-infected cultures, $167,592 \pm 20,849 \mathrm{dpm} / 10^{6}$ cells. The data represent the average of two determinations. Bars, SD. Chlamydiae-infected control cultures, (solid bars); chlamydiae-infected cultures plus $1.0 \mu \mathrm{M}$ sulfisoxazole, ( hatched bars); chlamydiae-infected cultures plus $1.0 \mu \mathrm{M}$ sulfisoxazole and $0.1 \mu \mathrm{M} \mathrm{pABA}$, (cross-hatched bars); chlamydiae-infected cultures plus $1.0 \mu \mathrm{M}$ sulfisoxazole and $1.0 \mu \mathrm{M}$ 5-CHO- $\mathrm{H}_{4}$ folate, (dotted bars); and chlamydiae-infected cultures plus $1.0 \mu \mathrm{M}$ sulfisoxazole and $10.0 \mu \mathrm{M} 5-\mathrm{CHO}-\mathrm{H}_{4}$ folate, (open bars).
5-CHO- $\mathrm{H}_{4}$ folate completely reversed the inhibitory effects of 1 $\mu \mathrm{M}$ sulfisoxazole on $C$. trachomatis $\mathrm{L} 2$ (Fig. 6 A, open bar). Surprisingly, even though methotrexate did not inhibit the growth of $C$. psittaci strain 6BC (Fig. 2), we found that $10 \mu \mathrm{M}$ 5-CHO- $\mathrm{H}_{4}$ folate could reverse the effects of $1 \mu \mathrm{M}$ sulfisoxazole (Fig. 6 B, open bar).

Our commercial preparation of folic acid was $\approx 98 \%$ pure, therefore it was possible that a small amount of contaminating pABA may have been present in our folate preparations. Since pABA was $\geq 100$ times more effective at antagonizing sulfa activity compared with $5-\mathrm{CHO}-\mathrm{H}_{4}$ folate it was possible that the reversion brought about by folates was really caused by contaminating pABA. To eliminate this possibility we tested the ability of folinic acid to reverse the inhibitory action of trimethoprim/ sulfisoxazole against $C$. trachomatis $\mathrm{L} 2$. The results clearly show that $5-\mathrm{CHO}-\mathrm{H}_{4}$ folate can antagonize the combined activity of the DHFR inhibitor trimethoprim and the DHPS inhibitor sulfisoxazole (Table II). As expected folic acid could not reverse trimethoprim inhibition of $C$. trachomatis $\mathrm{L} 2$ growth (data not shown).

Detection of in vitro DHFR activity in chlamydial extracts. To directly demonstrate that chlamydiae encode DHFR we conducted in vitro assays for DHFR using extract prepared from highly purified RBs as a source of enzyme (Table III). As a control experiment we conducted DHFR assays with crude extract prepared from logarithmically growing wild-type mouse L cells. We consistently detected DHFR activity in extracts prepared from $C$. trachomatis $\mathrm{L} 2$ as well as $C$. psittaci 6BC and francis RBs. The formation of tetrahydrofolate was dependent on the presence of RB extract, $\mathrm{NADPH}_{2}$, and $\mathrm{H}_{2}$ folate (data not shown). No activity was detected if folic acid was used as substrate. Mock infected mouse cell extract had essentially no DHFR activity.

Similar to in situ results we found that trimethoprim was a highly effective inhibitor of $C$. trachomatis L2 DHFR activity in vitro, however, it was less effective against $C$. psittaci $6 \mathrm{BC}$

Table II. Effect of 5-CHO-H, folate on Trimethoprim/ Sulfisoxazole-induced Inhibition of C. trachomatis Growth

\begin{tabular}{|c|c|c|c|c|}
\hline \multicolumn{3}{|c|}{ Addition to growth medium* } & \multicolumn{2}{|c|}{ DNA synthesis ${ }^{\ddagger}$} \\
\hline Sulfisoxazole & Trimethoprim & $\begin{array}{c}\text { 5-CHO-H } \\
\text { folate }\end{array}$ & $\begin{array}{l}\text { C. trachomatis } \\
\text { infected cells }\end{array}$ & $\begin{array}{l}\text { Percent } \\
\text { activitys }\end{array}$ \\
\hline & $\mu M$ & & & \\
\hline - & - & 一 & $145.2 \pm 20.4$ & 100 \\
\hline 1.0 & 1.0 & - & $19.0 \pm 8.5$ & 13 \\
\hline 1.0 & 1.0 & 1.0 & $67.4 \pm 8.6$ & 46 \\
\hline 1.0 & 1.0 & 10.0 & $147.4 \pm 12.3$ & 102 \\
\hline
\end{tabular}

* The indicated concentration of sulfisoxazole, trimethoprim, and/or 5-CHO- $\mathrm{H}_{4}$ folate was added to the culture medium immediately after infection ( 2 h p.i.) with C. trachomatis $\mathrm{L} 2 .{ }^{\ddagger}$ The effect of the various agents on chlamydiae growth was assessed by measuring $\left[6-{ }^{3} \mathrm{H}\right]-$ uridine incorporation into DNA at $20 \mathrm{~h}$ p.i. Confluent monolayers of $\mathrm{CHO} \mathrm{K1}$ cells $\left(3.0 \times 10^{6}\right.$ cells per plate cultured in the presence of $1 \mu \mathrm{g}$ cycloheximide/ml) were infected with $C$. trachomatis $\mathrm{L} 2$. For details see Methods and reference 17. Each value represents the mean \pm SD from two experiments. Results are expressed in $10^{3} \mathrm{dpm}$ per $10^{6}$ cells. ${ }^{8}$ The effect of the various agents on the incorporation of radiolabel into DNA is expressed as the percentage of the uninhibited control. 
Table III. Dihydrofolate Reductase Activity in Crude Extracts Prepared from Logarithmically Growing Host Cells and Purified Chlamydiae Reticulate Bodies

\begin{tabular}{|c|c|c|c|c|c|c|c|c|c|c|c|}
\hline \multirow[b]{3}{*}{ Substrate* } & \multirow[b]{3}{*}{ Inhibitor ${ }^{*}$} & \multicolumn{10}{|c|}{ Source of enzyme } \\
\hline & & \multicolumn{2}{|c|}{ Log growing mouse cells } & \multicolumn{2}{|c|}{$\begin{array}{l}\text { Mock-infected } \\
\text { mouse cells }\end{array}$} & \multicolumn{2}{|c|}{ C. trachomatis $\mathrm{L} 2$} & \multicolumn{2}{|c|}{ C. psittaci 6BC } & \multicolumn{2}{|c|}{ C. psittaci francis } \\
\hline & & $\begin{array}{l}\text { DHFR } \\
\text { activity" }\end{array}$ & $\%$ & $\begin{array}{l}\text { DHFR } \\
\text { activity }\end{array}$ & $\%$ & $\begin{array}{l}\text { DHFR } \\
\text { activity }\end{array}$ & $\%$ & $\begin{array}{l}\text { DHFR } \\
\text { activity }\end{array}$ & $\%$ & $\begin{array}{l}\text { DHFR } \\
\text { activity }\end{array}$ & $\%$ \\
\hline \multirow[t]{3}{*}{$\mathrm{H}_{2}$ folate } & - & $3.65 \pm 0.56$ & 100 & $<0.01$ & 100 & $2.34 \pm 0.56$ & 100 & $0.37 \pm 0.05$ & 100 & $1.87 \pm 0.39$ & 100 \\
\hline & TMP & $4.18 \pm 0.71$ & 114 & ND' & ND & $0.05 \pm 0.02$ & 2 & $0.25 \pm 0.04$ & 65 & $1.53 \pm 0.11$ & 82 \\
\hline & MTX & $0.45 \pm 0.06$ & 12 & ND & ND & $1.26 \pm 0.15$ & 54 & $0.03 \pm 0.02$ & 8 & $1.03 \pm 0.12$ & 55 \\
\hline Folic acid & - & $0.26 \pm 0.05$ & 7.1 & ND & ND & $<0.01$ & $<1$ & $<0.01$ & $<1$ & $<0.01$ & $<1$ \\
\hline
\end{tabular}

* The complete DHFR reaction mix contained either $100 \mu \mathrm{M} \mathrm{H} \mathrm{H}_{2}$ folate or $100 \mu \mathrm{M}$ folic acid as the substrate. For details of assay conditions, see Method. ${ }^{\ddagger}$ To assess the effect of trimethoprim (TMP) and methotrexate (MTX) on DHFR activity, a complete reaction mix minus substrate was incubated in the presence of $10 \mathrm{nM}$ TMP or $1 \mathrm{nM}$ MTX for $10 \mathrm{~min}$ at $4^{\circ} \mathrm{C}$. The reaction was initiated by the addition of $\mathrm{H}_{2}$ folate substrate and incubation was at $30^{\circ} \mathrm{C}$. ${ }^{8} \mathrm{Crude}$ extracts were prepared from the various sources as described in reference 17 . "Reactions were carried out at $30^{\circ} \mathrm{C}$ for $10 \mathrm{~min}$. DHFR activity is expressed as $\mathrm{nmol}_{4}$ folate formed/mg protein per min. Each value represents the mean $\pm \mathrm{SD}$ from two experiments. 'ND, not determined.

and francis DHFR activity in vitro (Table III). In agreement with previous observations that methotrexate is an effective in vitro inhibitor of DHFR activity from most bacterial and mammalian sources $(32)$, we found that it was active against in vitro DHFR activity of all three chlamydial strains.

\section{Discussion}

Although there was no conclusive evidence until recently (17), it has been assumed that chlamydiae require folates for the generation of thymidine nucleotides $(5,15)$. Furthermore, it has generally been accepted that all $C$. trachomatis strains are sensitive to sulfonamides whereas all $C$. psittaci strains, with the exception of $6 \mathrm{BC}$, are resistant to sulfa action $(1,4,5,12$, 18-20). A reasonable explanation for these findings was that C. trachomatis strains and C. psittaci $6 \mathrm{BC}$ were capable of synthesizing folates de novo whereas the remainder of the $C$. psittaci strains were not. Unlike the simple interpretation required to explain the action of sulfonamides against chlamydiae it has proven difficult to interpret results obtained using antifols that target DHFR $(5,19,33)$. One must be cautious when comparing various results obtained with DHFR inhibitors because many different host cell systems, i.e., chicken embryo and tissue culture cell lines from different mammalian species, have been employed and it has recently been shown that variations in methodology markedly influence chlamydial antimicrobial susceptibility results (34).

In agreement with earlier in situ observations $(12,18)$, we found that $C$. trachomatis $\mathrm{L} 2$ and $C$. psittaci $6 \mathrm{BC}$ were sensitive to sulfonamides. Furthermore, $C$. psittaci francis was resistant to sulfonamide, so long as folates were present in the culture medium. In addition our results indicate that trimethoprim was active against $C$. trachomatis $\mathrm{L} 2$ in situ but had no effect against either $C$. psittaci strain. Methotrexate inhibited the growth of $C$. trachomatis $\mathrm{L} 2$ and $C$. psittaci francis but did not effect $C$. psittaci 6BC growth. Previously Morgan (19) reported that $C$. psittaci $6 \mathrm{BC}$ was sensitive to aminopterin. We have consistently found that the growth of $C$. psittaci $6 \mathrm{BC}$ is resistant to a wide variety of antifols, including aminopterin (data not shown), methotrexate, and trimethoprim. It is sur- prising that $C$. psittaci $6 \mathrm{BC}$ was completely resistant to methotrexate especially since we found that $5-\mathrm{CHO}-\left[\mathrm{H}_{4}\right]$ folate could reverse sulfa inhibition of $C$. psittaci $6 \mathrm{BC}$ growth. One possible explanation for this finding is that $C$. psittaci $6 \mathrm{BC}$ may only be capable of transporting reduced folates. This would also explain why folinic acid was much more effective at reversing sulfa action against $C$. psittaci $6 \mathrm{BC}$ than was folic acid. It is of interest to note that Pediococcus cerevisiae is resistant to aminopterin and methotrexate but it requires 5-CHO- $\left[\mathrm{H}_{4}\right]$ folate for growth and has a specific transport system for reduced folates (35).

Since $C$. trachomatis $\mathrm{L} 2$ and $C$. psittaci $6 \mathrm{BC}$ are sensitive to sulfa action it has long been assumed that they must be capable of de novo folate synthesis. We have confirmed this by showing that: $(a)$ both these strains readily grow in folate-depleted $\mathrm{CHO}$ $\mathrm{K} 1$ cells, $(b)$ both incorporate exogenous $\left[{ }^{3} \mathrm{H}\right]$ pABA into folates, and $(c)$ extracts prepared from highly purified RBs of both strains contain DHPS activity. Most interestingly our results clearly indicate that, when growing in folate-depleted $\mathrm{CHO} \mathrm{K} 1$ cells, the normally sulfonamide-resistant $C$. psittaci francis becomes sensitive to the drug. The ability to incorporate $\left[{ }^{3} \mathrm{H}\right]$ pABA into folates and the detection of in vitro DHPS activity provides conclusive evidence for the existence of a de novo synthesis pathway in $C$. psittaci francis. As expected, sulfisoxazole prevented the in situ incorporation of $\left[{ }^{3} \mathrm{H}\right] \mathrm{pABA}$ into folates in all three chlamydial strains.

With folate-starved $\mathrm{CHO} \mathrm{K} 1$ cells as host we found that sulfonamide inhibition of all chlamydial strains could be reversed by the addition of exogenous pABA. $5-\mathrm{CHO}-\mathrm{H}_{4}$ Folate was able to antagonize sulfonamide activity in all three strains, a result that supports the suggestion that all strains have the capacity to transport reduced folates. Interestingly, even though it was less effective on a molar basis than $5-\mathrm{CHO}-\mathrm{H}_{4} \mathrm{fo}-$ late, folic acid could also effectively reverse sulfa inhibition of C. psittaci francis growth but was much less effective at antagonizing sulfa activity against $C$. trachomatis $\mathrm{L} 2$ or $C$. psittaci 6BC. Although many interpretations are possible, we believe that this result likely reflects the fact that the host cell folate transporter has a lower affinity for folic acid than 5-CHO- $\left[\mathrm{H}_{4}\right]-$ folate (30) and that $C$. psittaci francis is more efficient at ob- 
taining both reduced and nonreduced forms of folates from the host cell than are $C$. trachomatis $\mathrm{L} 2$ or $C$. psittaci 6BC. This hypothesis is also supported by the observation that when folates are present in the culture medium $C$. psittaci francis does not depend on de novo folate synthesis (as indicated by sulfa resistance) whereas $C$. trachomatis $\mathrm{L} 2$ and $C$. psittaci 6BC do (as indicated by sulfa sensitivity).

We consistently found that there was a difference in the composition of the intracellular folate pools between C. trachomatis and $C$. psittaci species. Although reduced folates were predominant in both chlamydial species, the C. trachomatis L2 folate pool was dominated by $\mathrm{H}_{4}$ folate whereas the $C$. psittaci 6BC folate pool was dominated by reduced folates carrying a one-carbon unit (i.e., $10-\mathrm{CHO}-\mathrm{H}_{4}$ folate). At the present time the significance of this difference is not known. However, it is interesting that, using the classical microbiological assay with Lactobacillus casei and Pediococcus cerevisiae, Colon and Moulder (31) also detected a difference in the composition of chlamydial species folate pools.

Our ability to detect DHFR activity in RB extracts from all three chlamydial strains confirm that the parasite does encode a DHFR. Results of in vitro DHFR assays indicate that the enzyme from all three strains is sensitive to methotrexate. In agreement with in situ results, we found that trimethoprim was a good inhibitor of $C$. trachomatis L2 DHFR activity in vitro. Both strains of $C$. psittaci were resistant to trimethoprim in situ and the in vitro DHFR activities of these two strains were less sensitive to trimethoprim than was $C$. trachomatis L2 DHFR activity in vitro. However, the difference in in vitro sensitivity between the species was not as great as might have been expected given the large difference in trimethoprim sensitivity in situ. This raises the possibility that there could be differences in the way $C$. trachomatis and $C$. psittaci metabolize trimethoprim or in their intrinsic permeability to the drug.

It is evident from the results presented that no simple concluding statement can be made with regard to folate metabolism in chlamydiae. The vast majority of free-living bacteria, both pathogenic and nonpathogenic, lack transport system(s) for preformed folates and thus depend on de novo synthesis. Recent studies on a variety of parasitic protozoa have shown that both de novo synthesis and salvage pathways for folates exist in eucaryotic intracellular parasites (36-40). Intracellular parasites spend most of their lives within host cells rich in nutrients. To obtain nondiffusible nutrients from their host, intracellular parasites must evolve (or obtain) suitable transport systems. Once a parasite has acquired the ability to obtain complex nutrients from its host it can afford to loose the capability to synthesize the given nutrient de novo. There would likely be a period of time when both capacities overlap and in some instances it may be necessary for the parasite to retain both pathways.

We believe that folate metabolism in chlamydiae is currently at this stage in evolution. All strains have an absolute dependence on folates for de novo thymidine synthesis. Originally this need was likely fulfilled via de novo folate synthesis as suggested by the ability of all strains tested to incorporate exogenous pABA into folates. More recently chlamydiae has obtained the necessary genetic information to allow them to acquire preformed folates from their host. The current status of the folate transport system(s) appears to vary from strain to strain. At one extreme $C$. psittaci francis fulfills its needs for folate strictly by transporting preformed host folates but does retain the capacity to synthesize de novo. At the other extreme C. psittaci 6BC appears to depend almost exclusively on its ability to synthesize folates de novo, however, it also has the capacity to transport reduced folate to a limited extent. Much of the discrepancy in the literature regarding the effectiveness of antifols against chlamydiae, both in situ and clinically, probably results from the parasites variable dependence on the two folate acquisition pathways.

\section{Acknowledgments}

We thank C. Allegra for providing us with $\mathrm{H}_{2} \mathrm{PtCH}_{2} \mathrm{OPP}$ and A. Andersen for performing the monoclonal antibody typing.

This research was supported by grants provided from the Manitoba Health Research Council (G. McClarty) and Medical Research Council of Canada (G. McClarty and R. Brunham). Grant McClarty is a recipient of a Manitoba Health Research Council Scholarship and Huizhou Fan is a recipient of a Manitoba Health Research Council Studentship.

\section{References}

1. Schachter, J. 1988. The intracellular life of chlamydia. Curr. Top. Microbiol. Immunol. 138:109-139.

2. Fraiz, J., and R. B. Jones. 1988. Chlamydial infections. Annu. Rev. Med. 39:357-370.

3. Storz, J. 1988. Overview of animal diseases induced by chlamydial infection. In Microbiology of Chlamydia. A. L. Barron, editor. CRC Press, Inc., Boca Raton, FL. 167-192.

4. Schachter, J., and H. D. Caldwell. 1980. Chlamydiae. Annu. Rev. Microbiol. 34:285-309.

5. Moulder, J. W. 1991. Interactions of chlamydiae and host cells in vitro. Microbiol. Rev. 55:143-190.

6. Moulder, J. W., T. P. Hatch, C.-C. Kuo, J. Schachter, and J. Storz. 1984 Genus I. Chlamydia. Jones, Rake and Stearns 1945,55 AL. In Bergey's Manual of Systemic Bacteriology. Vol. 1. N. R. Krieg, and J. G. Holt, editors. The Williams and Wilkins Co., Baltimore. 729-739.

7. Grayston, J. T., C.-C. Kuo, L. A. Campbell, and S.-P. Wang. 1989. Chlamydiae pneumoniae sp. nov. for Chlamydia sp. strain TWAR. Int. J. Syst. Bacteriol. 39:88-90.

8. Anand, N. 1983. Sulfonamides: structure-activity relationships and mechanism of action. In Inhibition of Folate Metabolism in Chemotherapy. G. H. Hitchings, editor. Springer-Verlag, New York. 25-54.

9. Shane, B., and E. L. R. Stokstad. 1985. Vitamin $B_{12}$-folate interrelationships. Annu. Rev. Nutr. 5:115-141.

10. Kisliuk, R. L. 1984. The biochemistry of folates. In Folate Antagonists as Therapeutic Agents. Vol. 1. F. M. Sirotnak, J. J. Burchall, W. B. Ensminger, and J. A. Montgomery, editors. Academic Press, Inc., New York. 2-68.

11. Maley, F., and G. F. Maley. 1990. A tale of two enzymes, deoxycytidylate deaminase and thymidylate synthase. Prog. Nucleic Acid Res. Mol. Biol. 39:4980.

12. Colon, J. I. 1962. The role of folic acid in the metabolism of members of the psittacosis group of organisms. Ann. NY Acad. Sci. 98:234-249.

13. Holterman, O. A., S. E. Mergenhagen, and H. R. Morgan. 1959. Factors related to psittacosis virus (6BC) growth. V. Folic acid-like factor in infected cells. Proc. Soc. Exp. Biol. Med. 100:370-372.

14. Hatch, T. P. 1976. Utilization of exogenous thymidine by Chlamydia psittaci growing in thymidine kinase-containing and thymidine kinase-deficient L cells. J. Bacteriol. 125:706-712.

15. Tribby, I. I. E., and J. W. Moulder. 1966. Availability of bases and nucleosides as precursors of nucleic acids in $L$ cells and the agent of meningopneumonitis. J. Bacteriol. 91:2362-2367.

16. McClarty, G., and G. Tipples. 1991. In situ studies on the incorporation of nucleic acid precursors into Chlamydia trachomatis DNA. J. Bacteriol. 173:4922-4931.

17. Fan, H., G. McClarty, and R. C. Brunham. 1991. Biochemical evidence for the existence of thymidylate synthase in the obligate intracellular parasite Chlamydia trachomatis. J. Bacteriol. 173:6670-6677.

18. Morgan, H. R. 1948. Studies on the relationship of pteroylglutamic acid to the growth of psittacosis virus (strain 6BC). J. Exp. Med. 88:285-294.

19. Morgan, H. R. 1952. Factors related to the growth of psittacosis virus (strain 6BC). I. Pteroylglutamic acid, vitamin $B_{12}$, and citrovorum factor. J. Exp. Med. 95:269-276. 
20. Huang, C., and M. D. Eaton. 1949. The reversal by PABA of sulfonamide inhibition of the viruses of lymphogranuloma venereum and mouse pneumonitis. J. Bacteriol. 58:73-88.

21. Rabinowitz, J. C. 1963. Preparation and properties of 5,10-methenyltetrahydrofolic acid and 10-formyltetrahydrofolic acid. Methods Enzymol. 6:814815.

22. Urlaub, G., and L. A. Chasin. 1980. Isolation of a Chinese hamster cell mutant deficient in dihydrofolate reductase activity. Proc. Natl. Acad. Sci. USA. 77:4216-4220.

23. Allegra, C. J., R. L. Fine, J. C. Drake, and B. A. Chabner. 1986. The effect of methotrexate on intracellular folate pools in human MCF-7 breast cancer cells. J. Biol. Chem. 261:6478-6485.

24. McMartin, K. E., V. Virayotha, and T. R. Tephly. 1981. High-pressure liquid chromatography of rat liver folates. Arch. Biochem. Biophys. 209:127-136.

25. Merali, S., Y. Zhang, D. Sloan, and S. Meshnick. 1990. Inhibition of Pneumocystis carinii dihydropteroate synthetase by sulfa drugs. Antimicrob. Agents Chemother. 34:1075-1078.

26. Baccanari, D., A. Phillips, S. Smith, D. Sinski, and J. Burchall. 1975. Purification and properties of Escherichia coli dihydrofolate reductase. Biochem istry. 14:5267-5273.

27. Wormser, G. P., and G. T. Keusch. 1983. Trimethoprim/sulfamethoxazole: an overview. In Inhibition of Folate Metabolism in Chemotherapy. G. H. Hitchings, editor. Springer-Verlag, New York. 1-23.

28. Jackson, R. C., and G. B. Grindey. 1984. The biochemical basis for methotrexate cytotoxicity. In Folate Antagonists as Therapeutic Agents. Vol. 1. F. M Sirotnak, J. J. Burchall, W. B. Ensminger, and J. A. Montgomery, editors. Academic Press Inc., New York. 290-315.

29. Flintoff, W. F. 1989. Methotrexate. In Drug Resistance in Mammalian Cells. R. S. Gupta, editor. CRC Press Inc., Boca Raton, FL. 1-14.

30. Dembo, M., and F. M. Sirotnak. 1984. Membrane transport of folate compounds in mammalian cells. In Folate Antagonists as Chemotherapeutic
Agents. F. M. Sirotnak, J. J. Burchall, W. B. Ensminger, and J. A. Montgomery, editors. Academic Press Inc., New York. 173-217.

31. Colon, J. I., and J. W. Moulder. 1958. Folic acid in purified preparations of members of the psittacosis group of micro-organisms. J. Infect. Dis. 103:109119.

32. Burchall, J. J. 1983. Dihydrofolate reductase. In Inhibition of Folate Metabolism in Chemotherapy. G. H. Hitchings, editor. Springer-Verlag, New York. 55-74.

33. Reeve, P., J. Taverne, and S. R. M. Bushby. 1968. Inhibition by pyrimidine analogues of the synthesis of folic acid by trachoma agent. J. Hyg. 66:295306.

34. Ehret, J. M., and F. N. Judson. 1988. Susceptibility testing of Chlamydia trachomatis: from eggs to monoclonal antibodies. Antimicrob. Agents Chemother. 32:1295-1299.

35. Mandelbaum-Slavit, F., and N. Grossowicz. 1970. Transport of folinate and related compounds in Pediococcus cerivisiae. J. Bacteriol. 104:1-7.

36. Allegra, C. J., J. A. Kovacs, J. C. Drake, J. C. Swan, B. A. Chabner, and H. Masur. 1987. Potent in vitro and in vivo antitoxoplasma activity of the lipid-soluble antifolate trimetrexate. J. Clin. Invest. 79:478-482.

37. Kovacs, J. A., C. J. Allegra, J. Beaver, D. Boarman, M. Lewis, J. E. Parrillo, B. Chabner, and H. Masur. 1989. Characterization of de novo folate synthesis in Pneumocystis carinii and Toxoplasma gondii: potential for screening therapeutic agents. 1989. J. Infect. Dis. 160:312-320.

38. Ellenberger, T. E., and S. M. Beverley. 1987. Biochemistry and regulation of folate and methotrexate transport in Leishmania major. J. Biol. Chem. 262:10053-10058

39. Kaur, K., T. Coons, K. Emmett, and B. Ullman. 1988. Methotrexate resistant Leishmania donovani genetically deficient in the folate-methotrexate transporter. J. Biol. Chem. 263:7020-7028.

40. Krungkrai, J., H. K. Webster, and Y. Yuthavong. 1989. De novo and salvage biosynthesis of pteroylpentaglutamates in the human malarial parasite Plasmodium falciparum. Mol. Biochem. Parasitol. 32:25-38. 